\title{
Procedures for monetary assessment of the labour component of organizations
}

\author{
Oksana Pirogova ${ }^{1}$, Roman Nuzhdin ${ }^{2}$, and Nadezhda Kondrashova ${ }^{2, *}$ \\ ${ }^{1}$ Peter the Great St. Petersburg Polytechnic University, 29 Polytechnicheskaya str., St. Petersburg, \\ Russia, 195251 \\ ${ }^{2}$ Voronezh State University of Engineering Technologies, 19 Revolyucii. Avenue, Voronezh, Russia, \\ 394000
}

\begin{abstract}
To obtain objective information about the level of staff remuneration and the possibilities of making effective managerial, including personnel, decisions, analytical procedures for the monetary assessment of the labour component of the organization have been developed. It is proposed to conduct a monetary assessment sequentially by means of implementing four analytical procedures for comparing the average monthly wage of personnel: with the established minimum wage; with a living wage; with the average wage in the region; with an average wage by type of economic activity. The results of a monetary assessment of the labour component of the Voronezh region sugar factories over a sixyear period indicate the economic inappropriateness of using the minimum wage and the subsistence minimum as criteria. First, the values of these indicators do not correspond to the level of economic development of the region and do not provide for the satisfaction of the real needs of the working-age population. Secondly, their use to verify compliance with legal requirements is correct only at the individual level, and not throughout the organization. It was found that the level of staff remuneration in the organizations under study is lower than the regional average in $82 \%$ of cases. The results of the sectoral assessment indicate the absence of a unified approach to the remuneration of the personnel of organizations for labour, including those included in one holding.
\end{abstract}

\section{Introduction}

The traditional approach to assessing the labor component is based on the need to fulfill a dynamic monetary ratio - the growth rate of labor productivity (in value terms) is ahead of the growth rate of labor costs. This position has a number of drawbacks that do not allow full use of remuneration for labor as an instrument of staff motivation. Firstly, the dynamic ratio, in our opinion, should be fulfilled if the size of staff remuneration is at the proper level and provides an opportunity for a decent life for the employee. Secondly, the annual growth of labor productivity in physical terms is limited by the technical capabilities of agro-processing enterprises. Therefore, its monetary assessment is largely determined by

\footnotetext{
*Corresponding author: kafedra17@ rambler.ru
} 
the level of prices for finished products, in comparison with which in practice there is no parity dynamics of labor costs [1].

Moreover, various subjects, taking into account their specific goals and objectives, are interested in diverse information on the level of remuneration [2]:

state bodies exercising control in the field of labor law - as a result of comparison with the minimum wage and the subsistence level to identify facts of non-compliance with applicable law;

potential employees and personnel - in the results of a regional comparison to select the most favorable conditions for labor relations;

employing organizations - in the results of regional and industry comparisons to develop measures to attract and retain the most qualified personnel;

IFTS - in the results of industry comparisons to assess the integrity of the taxpayer organization.

Thus, the minimum amount of analytical procedures for the monetary assessment of the labor component should include: a comparison of the level of remuneration with the minimum wage and the cost of living (to verify compliance with the requirements of the current legislation of the Russian Federation); comparing the level of remuneration at the regional and sectoral levels (to assess the competitiveness of the employing organization in the corresponding labor market and the risks associated with the loss of qualified personnel, as well as with inspections of regulatory bodies (table 1) [3].

Table 1. Analytical procedures for the monetary assessment of the labor component.

\begin{tabular}{|c|c|c|c|}
\hline Procedure & $\begin{array}{l}\text { Indicator Calculation } \\
\text { Methodology }\end{array}$ & Infobase & $\begin{array}{c}\text { Ratio } \\
\text { Characterization }\end{array}$ \\
\hline $\begin{array}{c}1- \\
\text { Comparison } \\
\text { of the average } \\
\text { monthly } \\
\text { salary of } \\
\text { employees } \\
\text { with the } \\
\text { minimum } \\
\text { wage }\end{array}$ & $\begin{array}{c}\mathrm{x}_{1}=\frac{S \text { av. mon. }}{\text { Wage min. }} \\
\text { S av.mon - average } \\
\text { monthly salary of } \\
\text { personnel, rub. } \\
\text { S av.mon }=\frac{F p}{N a v * 12} \\
\mathbf{F ~} \mathbf{p}-\text { payroll fund (amount } \\
\text { of accrued wages for the } \\
\text { year), rub. } \\
\mathbf{N} \text { av - the average number } \\
\text { of employees for the year, } \\
\text { people; } \\
\text { Wage min - the minimum } \\
\text { wage, rub. }\end{array}$ & $\begin{array}{c}\text { Payroll fund: } \\
\text { - section } 6 \text { "Production } \\
\text { costs" of the explanations } \\
\text { to the balance sheet and the } \\
\text { report on financial results; } \\
\text { - No. 1-enterprise (section } \\
6 \text { "Costs of production and } \\
\text { sale of products (goods, } \\
\text { works, services") } \\
\text { N av: } \\
\text { - "Information on the } \\
\text { average number of } \\
\text { employees for the previous } \\
\text { calendar year" (KND form } \\
1110018 \text { ); } \\
\text { Wage min: } \\
\text { - Federal Law of December } \\
\text { 28, 2017 No. 421-fz }\end{array}$ & $\begin{array}{c}\mathrm{x}_{1}<1-\text { legal } \\
\text { requirements are not } \\
\text { complied with; } \\
\mathrm{x}_{1} \geq 1 \text { - legal } \\
\text { requirements are } \\
\text { being implemented } \\
\\
\text { - Article } 133 \text { of the } \\
\text { Labor Code of the } \\
\text { Russian Federation; } \\
\text { - Law No. 83-FZ } \\
\text { "On the Minimum } \\
\text { Wage" of } \\
06 / 19 / 2000\end{array}$ \\
\hline $\begin{array}{c}2- \\
\text { Comparison } \\
\text { of the average } \\
\text { monthly } \\
\text { salary of } \\
\text { employees } \\
\text { with a living } \\
\text { wage }\end{array}$ & $\begin{array}{c}\mathrm{x}_{2}=\frac{\text { Sav.mon. }}{\text { MIN }} \\
\text { MIN - Living wage of the } \\
\text { able-bodied population, } \\
\text { rub. }\end{array}$ & $\begin{array}{l}\text { MIN: } \\
\text { - Federal Law "On the } \\
\text { Living Wage in the } \\
\text { Russian Federation" of } \\
\text { 10.24.1997 N 134-FZ }\end{array}$ & $\begin{array}{c}\mathrm{x}_{2}<1-\text { the level of } \\
\text { wages does not } \\
\text { cover the cost of the } \\
\text { basic consumer } \\
\text { basket; } \\
\mathrm{x}_{2} \geq 1 \text { - the level of } \\
\text { wages covers the } \\
\text { cost of the basic } \\
\text { consumer basket. }\end{array}$ \\
\hline $\begin{array}{c}3- \\
\text { Comparison } \\
\text { of the average }\end{array}$ & $\mathrm{x}_{3}=\frac{\text { Sav.mon. }}{\text { Sav.mon.reg }}$ & $\begin{array}{l}\text { S av.mon.reg. } \\
\text { - "The average monthly } \\
\text { nominal wage of }\end{array}$ & $\begin{array}{c}\mathrm{x}_{3}<1-\text { wage level } \\
\text { below the regional } \\
\text { average; }\end{array}$ \\
\hline
\end{tabular}




\begin{tabular}{|c|c|c|c|}
\hline $\begin{array}{l}\text { monthly } \\
\text { salary of } \\
\text { employees } \\
\text { with the } \\
\text { average size } \\
\text { of labor } \\
\text { remuneration } \\
\text { in the region }\end{array}$ & $\begin{array}{l}\text { S av. mon. reg - average } \\
\text { monthly salary of workers } \\
\text { in the region, rub. }\end{array}$ & $\begin{array}{l}\text { employees for a full range } \\
\text { of organizations in the } \\
\text { economy as a whole by } \\
\text { constituent entities of the } \\
\text { Russian Federation for } \\
\text { 2000-2017," data from the } \\
\text { Federal State Statistics } \\
\text { Service }\end{array}$ & $\begin{array}{l}\mathrm{x}_{3}=1-\text { the level of } \\
\text { remuneration } \\
\text { corresponds to the } \\
\text { regional average; } \\
\mathrm{x}_{3}>1 \text { - the wage } \\
\text { level is above the } \\
\text { regional average. }\end{array}$ \\
\hline $\begin{array}{c}4 \text { - } \\
\text { Comparison } \\
\text { of the average } \\
\text { monthly } \\
\text { salary of } \\
\text { employees } \\
\text { with the } \\
\text { average size } \\
\text { of labor } \\
\text { remuneration } \\
\text { by type of } \\
\text { economic } \\
\text { activity } \\
\text { (FEA) }\end{array}$ & $\begin{array}{l}\mathrm{x}_{4}=\frac{S \text { av.mon. }}{S \text { av. mon. ind. }} \\
\text { S av. mon. ind - average } \\
\text { monthly wage of workers } \\
\text { in the industry, } p .\end{array}$ & $\begin{array}{l}\text { S av.mon.ind.: } \\
\text { - "Number and } \\
\text { Remuneration of Industrial } \\
\text { Workers in the Voronezh } \\
\text { Region" Statistical Bulletin } \\
\text { from } 2012 \text { to } 2017 \text {. Code } \\
0220 .\end{array}$ & $\begin{array}{c}\mathrm{x}_{4}<1-\text { the level of } \\
\text { wages below the } \\
\text { average level by } \\
\text { type of economic } \\
\text { activity; } \\
\mathrm{x}_{4}=1-\text { the level of } \\
\text { wages corresponds } \\
\text { to the average level } \\
\text { by type of economic } \\
\text { activity; } \\
\mathrm{x}_{4}>1-\text { the wage } \\
\text { level is above the } \\
\text { average level by } \\
\text { type of economic } \\
\text { activity. }\end{array}$ \\
\hline
\end{tabular}

\section{Comparison of the average monthly salary of staff with the minimum wage}

In accordance with Art. 129 of the Labor Code of the Russian Federation, in force until September 1, 2007, the minimum wage is "the size of the monthly wage for the work of an unskilled worker who has fully worked out the time standard for simple work under standard working conditions. The amount of the minimum wage does not include compensation, stimulating and social payments. "The current version of the Labor Code of the Russian Federation does not provide this definition. Accordingly, in practice, there are cases when the salary is less than the minimum wage, and the amount accrued to staff is brought to the required level through various surcharges and compensation payments [4].

The results of comparing the average monthly wage of the personnel of sugar factories of the GC "Prodimex" in the Voronezh region with the minimum wage (procedure 1) indicate compliance with the requirements of the law (table 2) [5]. Throughout the study period, $x 1$ values were significantly higher than the minimum level (3-4 times). The best indicator values were recorded at enterprise $\mathrm{C} 7$ (average value of 4.59 units). At the same time, it should be borne in mind that the level of the indicator $x \_1 \geq 1$ at the enterprise level can only conditionally indicate compliance with the requirements of the law, since it must be performed at the level of each employee, otherwise there is a high probability of unscheduled inspections by labor inspections and other regulatory bodies [6].

In accordance with Article 133 of the Labor Code of the Russian Federation, the minimum wage cannot be lower than the living wage for the able-bodied population. However, this requirement was not fulfilled during the study period (Figure 1). Thus, the minimum wage in a certain sense is a "quasi-indicator", because:

does not reflect the level of income necessary to protect the interests of unskilled personnel;

serves solely for the formal reflection of the system of relations in the labor market;

the dynamics of the minimum wage is absolutely arbitrary and does not correspond to the real state and the pace of economic development [7]. 
On February 1, 2018, Law No. 421-FZ of December 28, 2017 entered into force, setting the minimum wage at $85 \%$ of the cost of living, as part of the state program to equalizing gradually the minimum wage with the cost of living. In accordance with this law, starting from February 1, 2019 and beyond, the minimum wage is set equal to the size of the subsistence minimum for the 2nd quarter of the previous year. With a decrease in the cost of living, the minimum wage remains at the same level as the previous year. In advance of the indicated schedule, the minimum wage was equal to the cost of living on May 1, 2018, when it amounted to 11,163 rubles [8].

This measure is aimed, firstly, at increasing the incomes of the least paid workers, who make up a wide segment of the population. Secondly, an increase in official staff income is anticipated, which should lead to an increase in revenues to extra budgetary funds (PFR, FSS, and MHIF). Thirdly, it is expected that the equalization of the minimum wage and the subsistence minimum will lead to an increase in budget revenues in the form of personal income tax and fines tied to the minimum wage [9].

\section{Comparison of the average monthly salary of staff with a living wage}

In this situation, the economic feasibility of using the minimum wage as a basic parameter in the monetary assessment of the labor component of the enterprise is very doubtful, despite the need to comply with legal requirements. Moreover, the requirement of the Tax Code of the Russian Federation to pay personal income tax reduces the minimum wage amount by another $13 \%$ (excluding tax deductions). Thus, the indicator $\mathrm{x} \_2$ has a greater analytical capacity in comparison with $x_{-} 1$; in any case, it will exceed the values of the latter and characterize the ability of the enterprise personnel to satisfy their minimum needs at the expense of income [10].

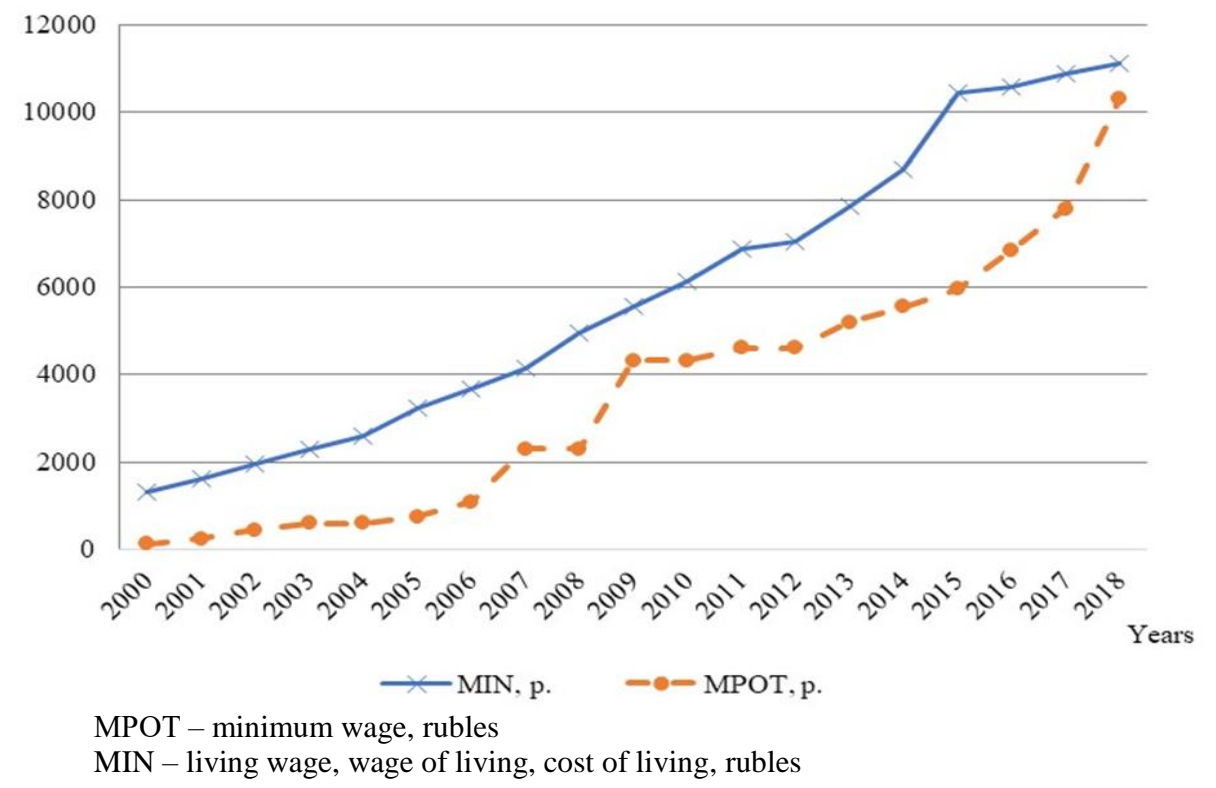

Fig. 1. Comparative dynamics of the minimum wage and cost of living in the Russian Federation. 
For the current stage of development of the domestic economy, a characteristic is a high proportion of the population with incomes below the subsistence level. The most intensive growth of this indicator in 1999-2000 was due to the manifestation of the consequences of the financial crisis (Figure 2) [11]. The decrease in the solvency of organizations against the background of the high single social tax rate $(35.6 \%)$ led to the use of illegal methods of tax optimization, in particular, to the payment of salaries in envelopes. Because of such actions, according to Rosstat data, in some regions, the estimated share of the population with incomes below the subsistence level exceeded $40 \%$ (for example, in the Voronezh region $41.9 \%$ in 2000 ).

In 2000 , a decrease in the single social tax rate to $26 \%$ with a $24 \%$ income tax rate significantly reduced the appropriateness of using the above tax optimization tools (Figure 2). Stabilization of economic processes in the country and reduction of the tax burden led to a gradual decrease in the share of the population with incomes below the subsistence level. The positive dynamics of the indicator in the Voronezh region, starting in 2010, is associated with the appointment of a new governor and the intensification of economic activity in the region [12].

At the same time, the abolition of UST in 2010 and the introduction of insurance premiums for $30 \%$ were negatively perceived by business entities. In their activities, they began to apply new optimization schemes in the form of registration of part-time staff. As a result, which, for example, in the Voronezh region since 2013, there is a lower level of the share of the population with incomes below the subsistence level compared with the Russian Federation, although the standard of living of the population has not changed significantly. In fact, employees carried out labor duties during all working days, and according to documents and reports, the time worked was only partially reflected, which, with statistical processing of information, made it possible to obtain a positive level and dynamics of the indicator [13].

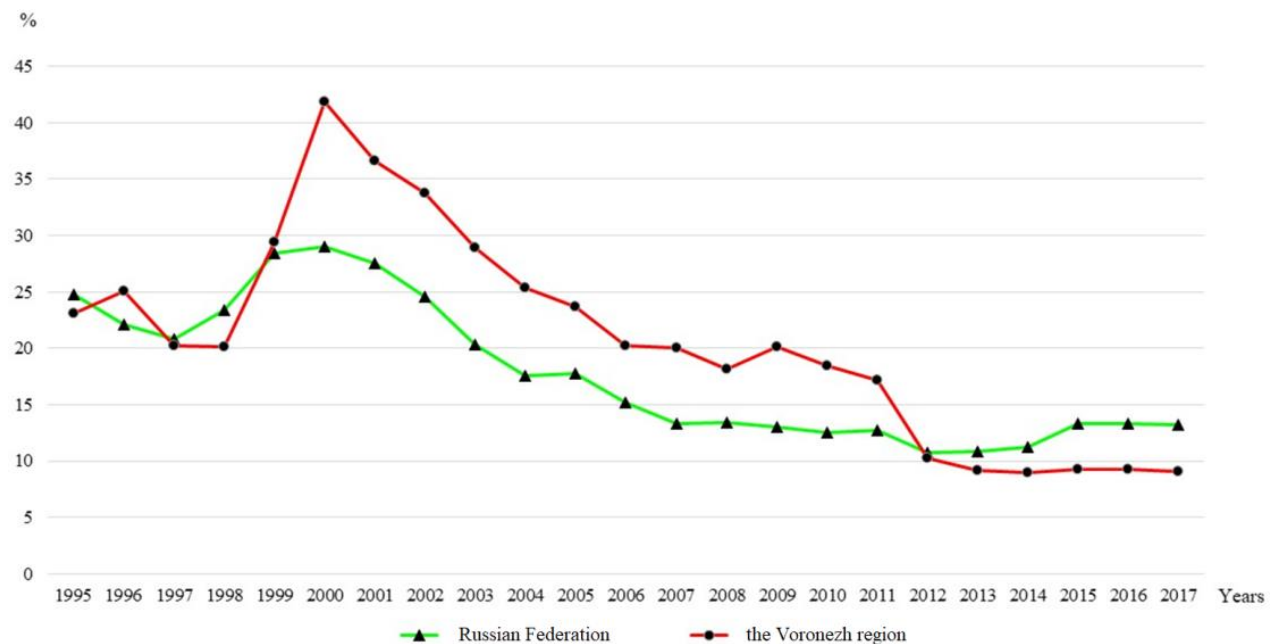

Fig. 2. The share of the population with cash incomes below the subsistence level $[2,3]$.

The results of analytical procedure 2 indicate that the average salary of the personnel of the sugar factories of the Voronezh region over the entire period was several times higher than the subsistence level (indicator range x2: 1.78-3.53 units). The obtained results of the assessment of the indicators $\mathrm{x} 1$ and $\mathrm{x} 2$ confirm our assumption that it is impossible to use the established minimum wage level and the cost of living as an instrument of staff motivation [14]. 


\section{Comparison of the average monthly wage of staff with the average wage in the region}

According to European law, the minimum wage providing a decent standard of living should be at least $60 \%$ of the average wage in the country [4]. The level of remuneration in different regions varies significantly, which is due to regional, including economic, characteristics. Therefore, in order to achieve the desired goals of a monetary assessment of the labor component of agricultural enterprises, it is necessary to consider the ratio of the average monthly salary of employees to the average wage in the region, which in a certain way characterizes the organization's competitiveness in the labor market [15].

The level of remuneration, including in the region, is of paramount importance for the motivation of skilled workers and their employment in a particular organization. In the Voronezh region, the growth in average wages is significantly ahead of the minimum wage dynamics, which is undoubtedly a positive aspect for the development of labor resources. However, a comparison of the level of wages with indicators for the Central Federal District and the Russian Federation is clearly not in favor of the region, and the existing imbalances are increasing annually (Figures 3 and 4) [14]. Indicator $\mathrm{x} 3$ allows you to judge the competitiveness of the enterprise and its ability to attract (retain) high-quality specialists in the regional labor market.

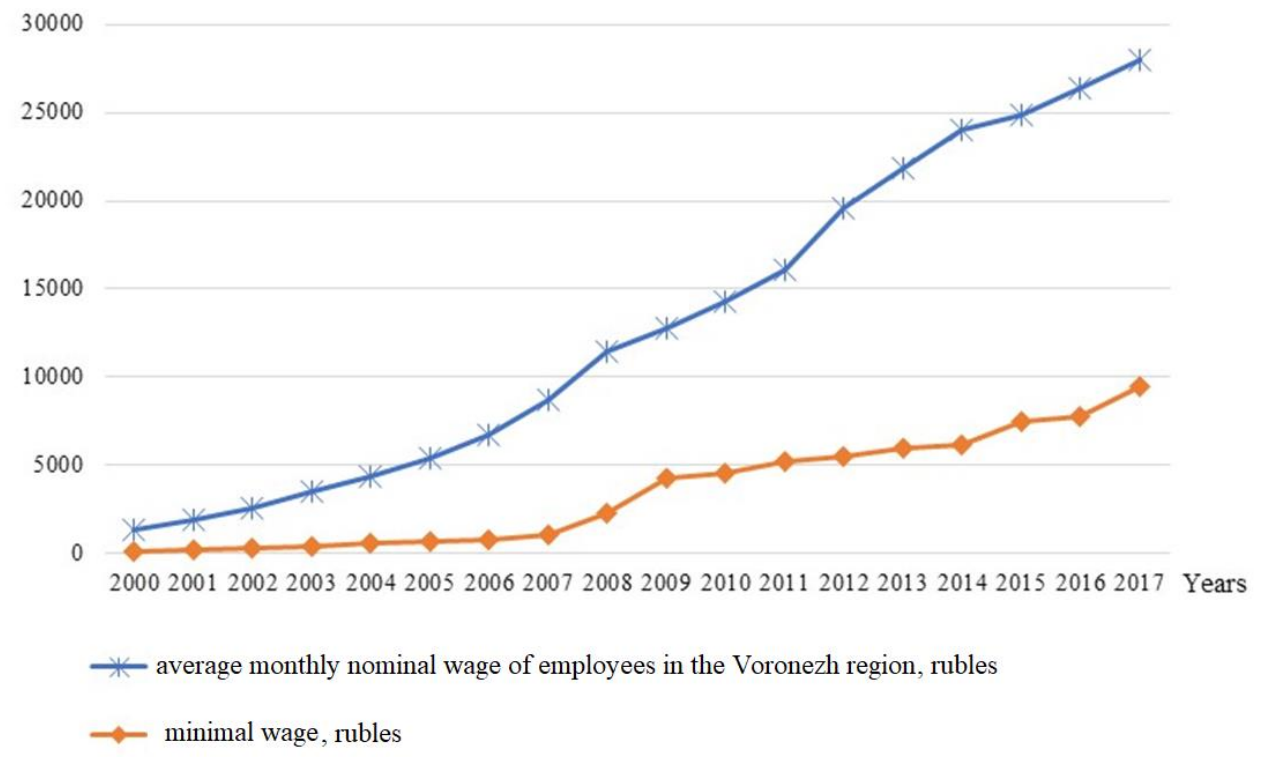

Fig. 3. Dynamics of the minimum wage and the average monthly nominal wage of employees for a full range of organizations in the Voronezh region (2000-2017).

The results obtained indicate the absence of a unified approach in Prodi-Mex-Sugar Asset Management to financing labor costs:

the average level of remuneration in the studied organizations does not depend on production capacity and financial results obtained;

multidirectional dynamics of indicators is observed in space and time: in most cases, the average level of remuneration in the studied enterprises is lower than the same indicator in the Voronezh region, which negatively affects the competitiveness of sugar production entities in the labor market.

We evaluate the current situation ambiguously, since workers and technical personnel, taking into account the specifics of sugar production, are forced to put up with 
insufficiently high levels of remuneration, since there are no other enterprises for employment in the specialty in the region.

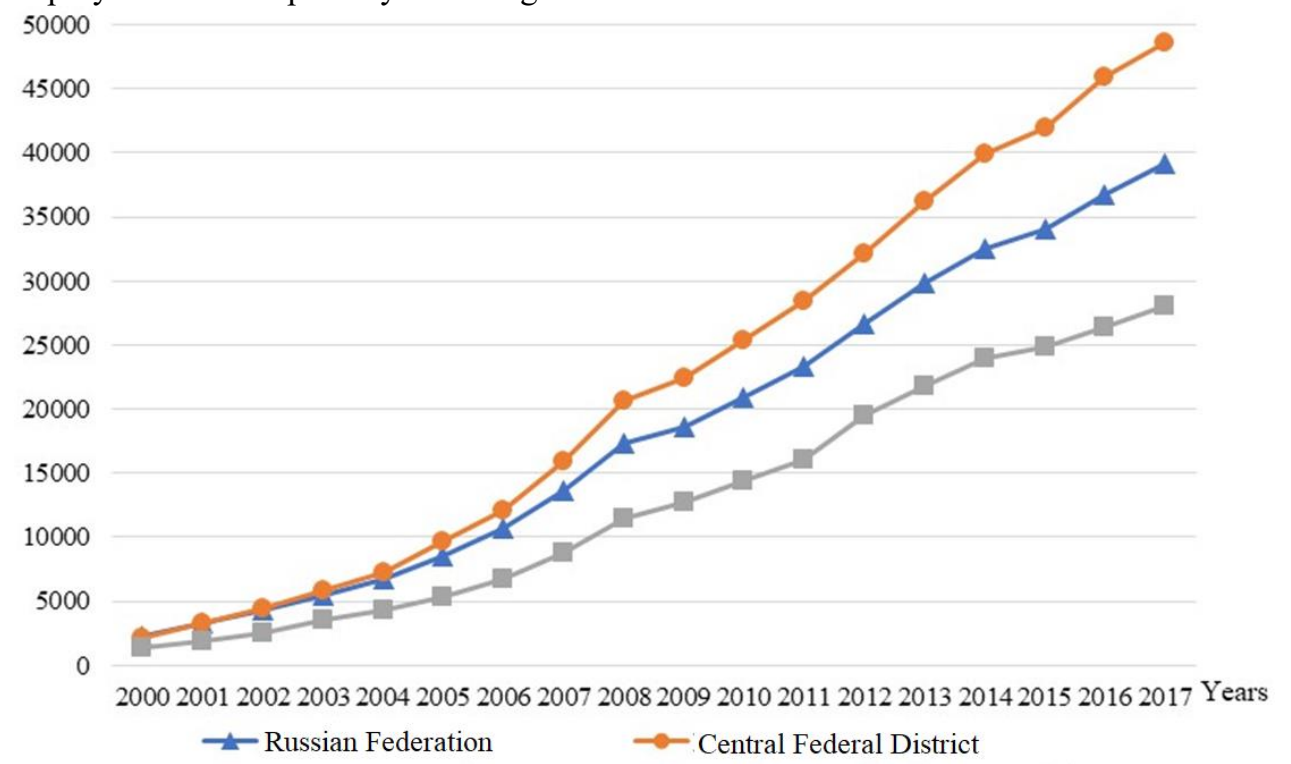

Fig. 4. Dynamics of the average monthly nominal accrued wages of employees for a full range of organizations in the whole of the Russian Federation, the Central Federal District and the Voronezh Region for 2000-2017.

\section{Comparison of the average monthly wage of staff with the average wage by type of economic activity (FEA)}

Unlike $\mathrm{x} \_3$, the indicator $\mathrm{x} \_4$ allows you to assess the competitiveness of enterprises of one type of economic activity in the territory of one region in the struggle for qualified personnel. Indicator $\mathrm{x} 4$ shows how many times the average monthly wage of one employee of an enterprise is more / less than the average wage by type of economic activity. In addition, the indicator $\mathrm{x} 4$ in accordance with paragraph 5 of the order of the Federal Tax Service of Russia dated May 30, 2007 No. MM-3-06 / 333 "On Approving the Concept of a Planning System for Field Tax Audits" is one of the criteria for assessing risks for taxpayers [15]. If the enterprise does not meet the condition $\mathrm{x}_{-} 4 \geq 1$, then this is the basis for receiving an information letter from the IFTS and including it in the plan for the field tax audit.

It should be noted that the values of the $\mathrm{x} 4$ indicator take into account industry specifics to a greater extent, since the data of 9 plants were used in calculating the average values, 8 of which are the object of study. A significantly larger number of indicator values, which exceeded the level of 1 unit, indicates that the average wage for the whole group of enterprises is lower than the same indicator for the region.

The best indicator values were achieved by enterprises $\mathrm{C} 7$ and $\mathrm{C} 1$. Interesting are the results for the enterprise C7, in which during 2012-2017 in five cases out of six cases the highest level of wages among sugar factories was noted. At the same time, the C7 enterprise is not distinguished by high production capacity, however, it has been possible to achieve significantly better indicator values. In addition to enterprise $\mathrm{C} 7$, the necessary condition $\mathrm{x} 4>1$ was fulfilled at enterprise $\mathrm{C} 1$, which has one of the modern production sites with a high processing capacity of beet raw materials. 
Thus, in the case of non-compliance with the conditions $\times 3>1$, the management of sugar factories and the management company should pay close attention to the implemented tools for motivating personnel, primarily production units; $x 4>1$ - nonproduction units in order to retain the most qualified personnel.

\section{Conclusion}

It is advisable to use the developed methodological tools for the formation of parity relations, ensuring the achievement of the strategic and tactical goals of organizations, as well as increasing staff motivation to achieve high results of labor activity.

\section{References}

1. R.V., Nuzhdin, E.V., Endovitskaya E.V., Assessment of the raw and labor components of sugar beet production: methodological justification. Sugar 11, $50-54$ (2018)

2. A.M., Matyagina, E.V., Smirnova, Environmentally responsible business (Moscow, FORUM, 2011)

3. K.P., Kolotyrin, Economic instruments for stimulating environmental activities. Bul. of the Saratov St. Tech. Univ. 1 (37), 186-196 (2009)

4. S.N., Bobylev, A. Sh., Khodjaev, Envir. Ec.: Textbook Moscow: INFRA-M. (2007)

5. A.A., Abdalhussein, M.S., Santalova, Human potential and human capital in the production activity of an enterprise. Soc. and ec. Phenom. and proc. 6 (052) (2013)

6. S.V., Nenasheva, Human capital: essence and structure. Izvestiya OSAU, 4 (36-1), $151-153(2012)$

7. L., Thurow, Inv. in Hum. Cap. Belmont (1970)

8. E.G., Flamholtz, Hum. Res. Acc.. N. Y., Jossey-Bass Publ. (1985)

9. A., Sen A, Develop. as Freed. New Publishing (2004)

10. T., Schultz, Invest. in Hum. Cap. Ec. Growth - an American Problem. Englewood Cliffs (1964)

11. J., Fitzenz, Return on investment in staff (2006)

12. L., Prusak, How to turn knowledge into value: Solutions from the IBM Institute for Business Value. Alpina Business Books, 248 (2006)

13. D.A., Kiryanov, Methods of human capital assessment: analysis of objectivity and sufficiency of initial data. Theory and practice of social development, № 3 (2012)

14. O.E., Pirogova, The approach to assessing the intellectual capital of a commercial enterprise within the framework of the VBM concept. News of St. Pet. St. Univ. of Ec. No. 2 (116), 102-109 (2019)

15. V., Plotnikov, O., Pirogova, Key Competencies as an Enterprise Value Management Tool. Proc. of the 31st Int. Business Inf. Man. Ass. Conf. (IBIMA) «Innovation Man. and Ed. Excell. through Vision», 1716-1721, Milan, Italy (2018). 